\title{
Systematics and faunistics of Neotropical Euliina, 2: Direconta gen. $\mathbf{n}$.
}

\author{
JÓZEF RAZOWSKI $^{1 *}$, VITOR O. BECKER ${ }^{2}$ \\ ${ }^{1}$ Institute of Systematics and Evolution of Animals, PAS, ul. Sławkowska 17, \\ 31-016 Kraków, Poland \\ ${ }^{2}$ Reserve Serra Bonita, PO Box 01, 45880-970 Camacan, BA, Brazil
}

\begin{abstract}
The new euliine genus Direconta and its five new Brazilian species (D. gnesia sp. n., $D$. recondita sp. n., D. barrasiana sp. n., D. curitibana sp. n., and $D$. lentigana sp. n.) are described and illustrated.

KEY WORDS: Tortricidae, Tortricinae, Cochylini: Euliina, new genus, new species, Neotropics, Brazil.
\end{abstract}

\section{INTRODUCTION}

This contribution deals with a new genus and five species which are rescricted to the Brazilian states of Paraná, Minas Gerais, and Rio de Janeiro.

KuZNETZOV \& STEKOLNIKOV (1977) divided Cochylini into two subtribes, Cochylina and Euliina (the latter as a new taxon). In a recent phylogenetic analysis based on molecular data, REGIER et al. (2012) formally synonimized Euliini with Cochylini, and proposed the use of the two taxa as subtribes, in conformance with KUZNETZOV \& STEKOLNIKOV (1977). In this series, for practical purposes, we treat euliines as a subtribe of Cochylini.

\footnotetext{
* Corresponding author: razowski@isez.pan.krakow.pl
} 


\section{MATERIAL}

The specimens examined for this paper were collected by the second author. The types of the new species are housed in the BECKER collection, Camacan, Brazil, and will eventually be deposited in a major Brazilian Museum.

The numbers cited on the labels of the specimens are the entry numbers in the register book of the second author.

Abbreviations: GS - genitalia slide, MK - Marek KOPEĆ, WZ - Witold ZAJDA.

RESULTS

\section{Direconta gen. $\mathbf{n}$.}

Type species: Direconta gnesia sp. n.

\section{Diagnosis}

In the male genitalia, Direconta is similar to Gravicornutia RAZOWSKI \& BECKER, 2001 but differs from it in having a well sclerotized costa of the valva terminating in a spine, a simple sacculus with terminal spines, a simple transtilla, and two or three moderately long cornuti, whereas in Gravicornutia there is only one very large cornutus.

\section{Description}

Wing span 12-16 mm. Forewing moderately expanding terminad; costa slightly convex, without costal fold; termen weakly oblique, almost straight or sinuate. Colouration cryptic; ground colour of forewing whitish yellow, strigulation brownish yellow; markings black in form of remnants of usual Tortricinae shape or spots, if present.

Male genitalia. Tegumen slender; pedunculi moderately long, slender; uncus slender, uniformly broad, moderately long; socius large, drooping, slightly expanding terminally; arm of gnathos slender, terminal plate short; vinculum simple, broadening near middle; valva long, slender; dorsobasal part of costa long, upcurved, with strongly sclerotized, slender inner edge extending distad to end of valva, terminating in a distinct spine; remaining part of edge simple, exceptionally (in Direconta lentigana) with additional spine medially; sacculus simple; transtilla simple, belt-shaped; juxta with terminal, lateral, or median processes; phallus large, coecum penis broadly rounded; caulis small; cornuti strong capitate spines.

Female genitalia unknown. 
RAZOWSKI J. and BECKER O.V.: Systematics and faunistics of Neotropical Euliina, $2 \quad 277$

\section{Biology and distribution}

The moths were collected in January and May at altitudes of 800, 920, 1300, 2100 and $2300 \mathrm{~m}$ in the states of Paraná, Minas Gerais and Rio de Janeiro, Brazil.

\section{Etymology}

The name is an anagram of the specific name recondita, one of the Direconta species.

\section{Remarks}

The newly described species are the only five representatives of the genus, and thus are compared only with one another. The data on their biology are given on the cited labels.

\section{Direconta gnesia sp. $\mathbf{n}$.}

(Figs 1, 2,11)

\section{Dagnosis}

In facies, Direconta gnesia is similar to D. lentigana, but the latter has a darker forewing with some black dots, and a strigulated hindwing; in the genitalia, $D$. gnesia differs from $D$. lentigana chiefly by the two cornuti (three in $D$. lentigana) and the absence of the dorsomedian spine of the valva.

\section{Description}

Wing span $16 \mathrm{~mm}$. Head whitish cream, lateral part of labial palpus and thorax tinged brown. Forewing expanding terminad; apex pointed; costa almost straight; termen delicately depressed beneath uncus. Wing whitish cream delicately strigulated brownish yellow. Cilia yellowish white. Hindwing yellowish white with some yellowish grey dots; cilia whitish.

Male genitalia (Figs 1, 2). Uncus slender; socii long, broadening terminally; arm of gnathos and terminal plate slender, simple; valva broad to middle, concave subterminally, expanding, armed with apical spine; one long tactile seta in middle of valva subdorsally; sacculus reaching mid-length of valva; transtilla belt-shaped, well sclerotized dorsally; juxta with elongate dorsal corners; phallus moderately broad; cornuti two, larger cornutus with broad capitulum, shorter with small capitulum.

\section{Type material}

Holotype male: "Brasil: 2100 m, Itatiaia: R[io de]J[aneiro], 26. I. 1993, V.O. BECKER Col; Col. BECKER 86509”; GS 73 WZ. 


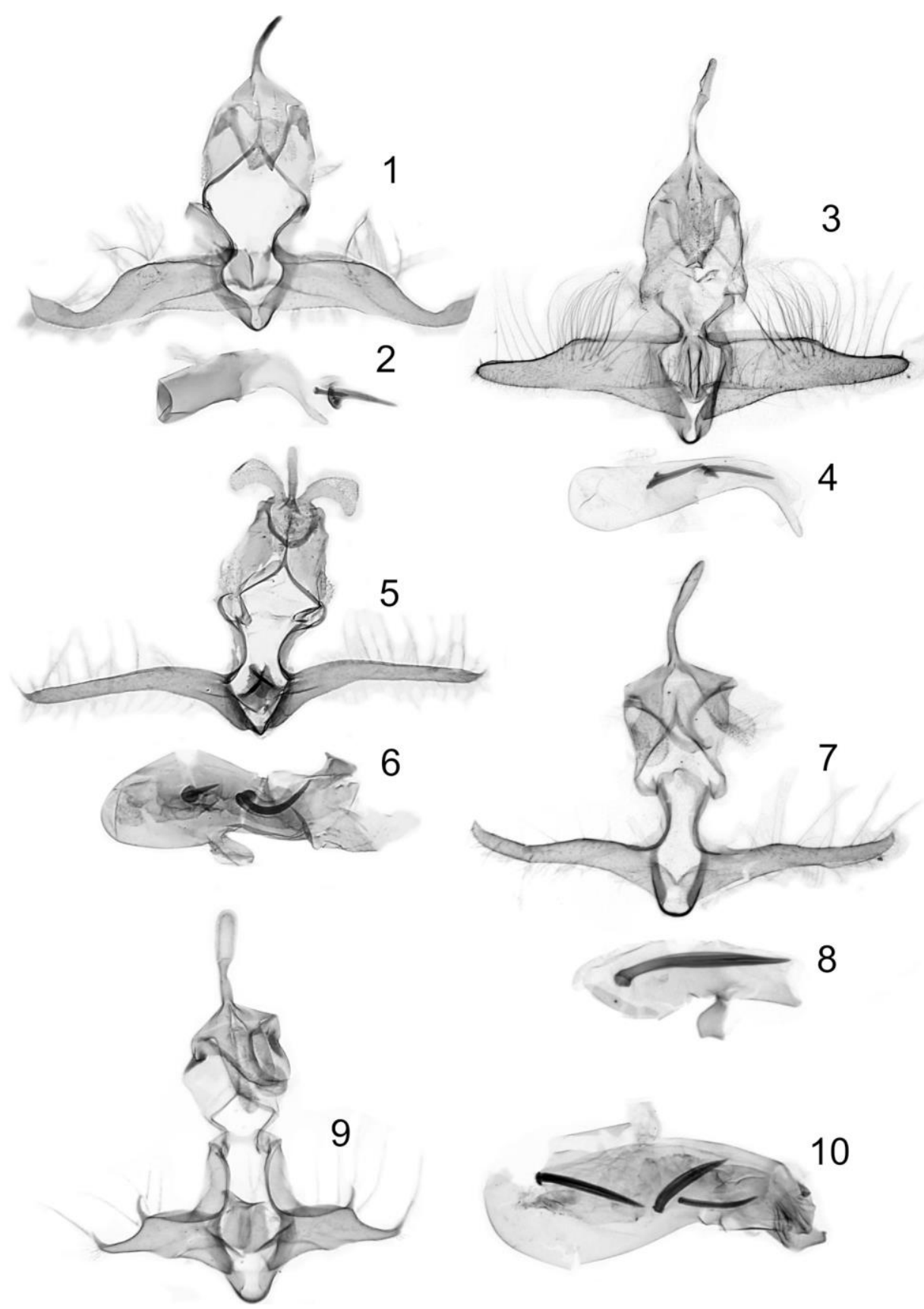

Figs 1-10. Male genitalia: 1, 2 - Direconta gnesia sp. n., holotype, 3, 4-D. barrasiana sp. n., holotype, 5, 6-D. recondita sp. n., holotype, 7, 8-D. curitibana sp. n., holotype, 9, $10-D$. lentigana sp. n., holotype. 

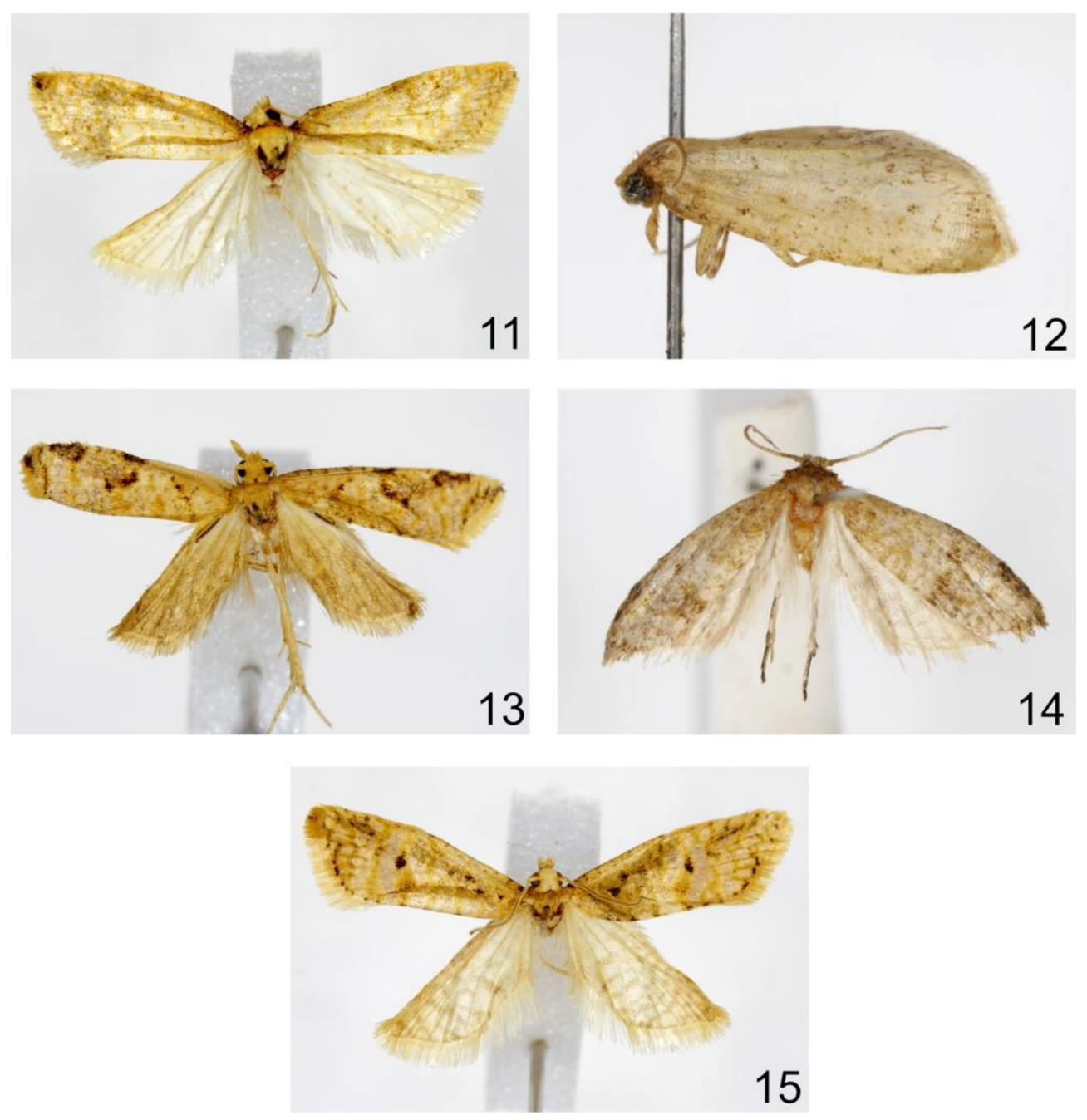

Figs 11-15. Adults: 11 - Direconta gnesia sp. n., holotype, 12 - D. barrasiana sp. n., holotype, 13 - D. recondita sp. n., holotype, $14-$ D. curitibana sp. n., holotype, $15-D$. lentigana sp. n., holotype.

\section{Etymology}

The epithet refers to the generic position of the species; Greek: gnesis - of right origin. 


\section{Direconta barrasiana sp. $\mathbf{n}$.}

(Figs 3, 4, 12)

\section{Diagnosis}

D. barrasiana is most similar to $D$. gnesia from which it differs by the longer uncus, the broader and not dorsally upcurved distal part of the valva, the longer postmedian part of the aedeagus, and cornuti of nearly equal length.

\section{Description}

Wing span $14 \mathrm{~mm}$. Head and thorax brownish cream. Forewing expanding somewhat terminad; costa weakly, gradually convex; termen oblique. Ground colour yellowish with slight brownish admixture and indistinct ferruginous cream strigulae and costa dots. Markings atrophied. Cilia damaged. Hindwing creamish grey, cilia paler.

Male genitalia (Figs 3, 4). Uncus long, slender, slightly expanding postmedially; gnathos arms slender; valva broad to middle, slender, tapering slightly terminad in posterior half, armed with small dorsoterminal spine; sacculus broad basally, simple; transtilla weak; phallus and coecum penis large; aedeagus bent subterminally with long ventral termination; cornuti two moderately large, capitate spines nearly equal in length.

Female unknown.

\section{Material examined}

Holotype male: "Banhado, Quatro Barras, Paraná, Brasil - 800 m, 1. VIII. 1970, BECKER \& LAROCA; Col. BECKER 24486"; GS 35253 MK.

\section{Etymology}

The specific epithet refers to the type locality of this species.

\section{Direconta recondita $\mathbf{s p .} \mathbf{n}$.}

(Figs 5, 6, 13)

\section{Diagnosis}

$D$. recondita differs from $D$. gnesia by the brownish cream forewing ground colour and blackish remnants of the usual tortricine markings, and in the male genitalia chiefly by the very slender, long, almost uniformly broad valva. 


\section{Description}

Wing span $12 \mathrm{~mm}$. Head and thorax brownish cream. Forewing expanding weakly terminad; costa slightly convex; termen moderately oblique, straight. Ground colour brownish cream sprinkled and finely strigulated pale brownish. Markings blackish, consisting of costal and median spots representing median fascia, subapical triangular blotch and apical spot; indistinct striae postbasally and subterminally. Cilia paler than ground colour. Hindwing pale brownish with some darker strigulae; cilia pale brownish cream.

Male genitalia (Figs 5, 6). Uncus slender, somewhat shorter than socius; socius curved, distinctly expanding terminally, extending laterally; arms of gnathos slender, terminal plate small; valva moderately broad at base, slender postbasally especially in distal half, with terminal spine directed upwards; sacculus short, oblique; transtilla a simple, weakly sclerotized band; juxta extending dorsally; phallus large, broad; cornuti two unequal-sized capitate spines, one strongly bent.

\section{Type material}

Holotype male: "Brasil: M[inas]G[erais], Caraca 1300 m, 7-10. V. 1996, V.O. BECKER Col; Col. BECKER 108176”; GS 424 WZ.

\section{Etymology}

The specific name refers to the systematic position of the species; Latin: recondita hidden.

\section{Direconta curitibana sp. $\mathbf{n}$.}

(Figs 7, 8, 14)

\section{Diagnosis}

Direconta curitibana is closely related to $D$. recondita but differs from it by the creamish hindwing, the long, terminally broadening uncus and the single, large cornutus.

\section{Description}

Wing span $9 \mathrm{~mm}$. Head and thorax greyish cream. Forewing weakly expanding terminad; costa slightly convex; apex pointed; termen straight, oblique. Ground colour greyish cream; strigulae and transverse, slightly oblique pale brownish grey lines; termen edged more brownish. Markings greyish brown: base of wing suffused; median fascia broad. interrupted medially, marked with brown dots; subterminal blotch poorly defined. Cilia whitish. Hindwing creamish; cilia paler. 
Male genitalia (Figs 7, 8). Uncus long, slender to middle, much broader posteriorly, rounded apically; socius large, broad, rounded apically; gnathos arm moderately broad, terminal part well developed; valva slender, twice as broad in distal part to dorsal angulation as in posterior half; latter slightly upcurved with dorsoterminal spine; subdorsal sclerite of basal part of valva extending dorsally; transtilla a slender band; phallus large with short ventral termination; coecum penis rounded; cornutus almost as long as aedeagus with weak capitulum.

Female unknown.

\section{Material examined}

Holotype male: "Curitiba, Paraná, Brasil - 920 m, 20. XII. 1974, V.O. BECKER col.; Col. BECKER 5272"; GS 35239 MK; Paratypes 3 males: one labelled as above, "Col. BECKER 5268 and one with collection Nr. 5270"; and one from "Banhado, Quatro Barras, Paraná, 800 m, 1. VIII. 1970, BECKER \& LAROCA; Col BECKER 34486”, GS 35248 MK.

\section{Etymology}

The name refers to the type locality of the species, Curitiba in Paraná.

\section{Direconta lentigana sp. $n$.}

(Figs 9, 10, 15)

\section{Diagnosis}

In facies, $D$. lentigana is similar to $D$. gnesia but $D$. lentigana has black dots on the brownish cream forewing ground colour. In the male genitalia, $D$. lentigana is distinguished chiefly by the presence of a spine from mid-costa of the valva and three cornuti in the vesica.

\section{Description}

Wing span $16 \mathrm{~mm}$. Forewing distinctly expanding terminad; costa straight to middle; termen oblique, sinuate. Ground colour dirty cream, densely strigulated brownish yellow and brownish grey; grey dots along dorsum and costa and greyish strigulae subterminally. Markings limited to some blackish dots and black spot at end of median cell. Cilia paler and yellower than ground colour. Hindwing cream tinged brownish at apex, strigulated greyish; cilia cream white.

Male genitalia (Figs 9, 10). Uncus long, broad in posterior half rounded apically; socius long; gnathos slender; valva proportionally short, broad to middle, slender posteriorly; one spine at mid-dorsum of valva, one apically; sacculus reaching mid-length of valva; transtilla short, convex, weakly sclerotized medially; juxta with medioposterior process; phallus very large, vesica with three unequally sized cornuti. 


\section{Type material}

Holotype male: "Brasil: R[io de]J[aneiro], Itatiaia, 2300 m, 26.I.1993, V.O. BECKER Col; Col. BECKER 86510"; GS 366 WZ.

\section{Etymology}

The name refers to the forewing colouration; Latin: lentigana - freckled.

\section{REFERENCES}

KuZnETZOV V.I., SteKolnikov A.A. 1977. Functional morphology of the male genitalia and phylogenetic relationships of some tribes in the family Tortricidae (Lepidoptera) fauna of the Far East. Trudy Zoologicheskogo instituta Akademii nauk SSSR, 70: 65-97. (in Russian)

Regier J.C., Brown J.W, Mitter C., BaiXeras J., Cho S., Comings M.P., Zwick A. 2012. A molecular phylogeny for the leaf-roller moths (Lepidoptera: Tortricidae) and its implications for classification and life history evolution. PLoS One, 7 (4): 1-17.

Received: 16 April 2019

Accepted: 14 August 2019 